\title{
ECONOMIC EVALUATION OF NITROGEN RESPONSE CURVE IN MAIZE
}

\author{
(Received: 20.10.2013)
}

\author{
By \\ Sh. A. Mansour, S.K. A.Ismail* I. Kh. Abbas** and S. M. H. Ali Eissa ** \\ Maize Research Department, Field Crops Research Institute, Agriculture Research Center, Giza. \\ *Agronomy Department, Faculty of Agriculture, Fayoum University. \\ ** Center Laboratory for Design \& Statistical Analysis Research, \\ Agriculture Research Center, Giza, Egypt.
}

\begin{abstract}
Three field experiments were carried out at Sids Agricultural Research Station, Agricultural Research Center (ARC) during the seasons 2010, 2011 and 2012. The objectives of this study were to: 1) Evaluate the nitrogen levels effects $(0,30,60,90,120$ and $150 \mathrm{Kg} \mathrm{N} / \mathrm{fed})$ on grain yield (ard/fed) of Single Cross 10 (S.C 10), 2) Determine the response of grain yield to $\mathrm{N}$ fertilizer, and 3) Estimate the economic of $\mathrm{N}$ rate in maize. The highest grain yield (ard/fed) was produced by supplying $150 \mathrm{Kg} \mathrm{N} / \mathrm{fed}$ in the three seasons. Quadratic model was the best of the tested models for describing the relationship between grain yields of maize hybrid (S.C 10) to $\mathrm{N}$ fertilizer. The economic optimum $\mathrm{N}$ rates $(121.053,120.645$ and $120.129 \mathrm{Kg} \mathrm{N} / \mathrm{fed}$ ) were produced by adding $(24.77,21.69$ and $25.17 \mathrm{ard} / \mathrm{fed})$, respectively, and the net return (£.E 4780.61, 5682.78 and 6795.9/fed) in the three seasons, respectively.
\end{abstract}

Key words: economic evaluation, nitrogen response curve, maize.

\section{INTRODUCTION}

The economic optimum fertilizer rate is essential to maximize profitability and minimize potential negative environmental impacts of nitrogen fertilizer use. Decisions regarding the optimum rate of fertilizer require fitting some type of model to the data on yield collected when several fertilizer rates are applied. Cerrato and Blackmer (1990) fitted five response models namely: linear plus plateau, quadratic, quadratic plus plateau, exponential and square root to maize yield data in the USA. They found that quadratic plus plateau model was the best described response of maize yield to nitrogen fertilizer. Economic optimum rate of $\mathrm{N}$ fertilizer was 184 $\mathrm{kg} \mathrm{N} \mathrm{ha}{ }^{-1}$. Using quadratic response functions and a 1:10 $\mathrm{N}$ fertilizer : maize price ratio, Oberle and Keeney (1990) reported economic optimum N rates between 160 and $210 \mathrm{lb} /$ acre on irrigated sandy soils and between 90 and $150 \mathrm{lb} / \mathrm{acre}$ on fine textured soils. In Wisconsin, USA, the $\mathrm{N}$ fertilizer rate required to maximize net return with maize was 160 to $170 \mathrm{lb} / \mathrm{acre}$ in high -yielding and low-yielding years (Vanotti and Bundy, 1994). Schlegel et al. (1996) demonstrated that in Kansas, USA, the economic optimum $\mathrm{N}$ rate for irrigated continuous maize was about $160 \mathrm{lb} / \mathrm{acre}$. Response of maize grain yield to $\mathrm{N}$ fertilization under different plant densities was studied by ElDouby, et al. (2001). They found that the relation between grain yield and $\mathrm{N}$ fertilizer was described by the quadratic model.

Yield of maize is the integrated effect of many variables that affect plant growth during the season. Growth analysis and relative contribution studies may help in interpreting the results and perhaps lead the breeder to get better cultivars and good evaluation for the agricultural practices.

The objectives of this study were (i) Investigate the effect of $\mathrm{N}$ fertilizer on grain yield ( $\operatorname{ard} / \mathrm{fed})$ to determine the response degree of grain yield to $\mathrm{N}$ fertilizer, (ii) Calculate the economic optimum $\mathrm{N}$ rates for maize yield. The techniques utilized include fitting polynomial curves and performing economic analysis of the response curves.

\section{MATERIALS AND METHODS}

The experiments were carried out to study the effect of six nitrogen fertilizer levels $(0,30,60$, 90,120 and $150 \mathrm{~kg} \mathrm{~N} / \mathrm{fed}$ ) on maize grain yield of cultivar Single Cross 10 (S.C 10), to determine the degree of yield response to nitrogen fertilization as well as to estimate the economic optimum $\mathrm{N}$ rate. Three field experiments were conducted at Sids Agricultural Research Station, Agricultural 
Research Center (ARC) in 2010, 2011 and 2012 seasons.

The experimental treatments were arranged in four replicates in a randomized complete block design. Plots consisted of five ridges, $3 \mathrm{~m}$ long and $70 \mathrm{~cm}$ apart. Planting was done in hills spaced $25 \mathrm{~cm}$ along the ridge. Plot area was 3X3.5 (10.5 $\mathrm{m} 2$ ). At harvest time, grain yield (ard./fed) was estimated on the basis of plot area $(10.5 \mathrm{~m} 2)$ and was adjusted to $15.5 \%$ moisture content. Mechanical and chemical analysis of the soil at the experimental sites Jackosn (1973) are presented in Table (1). All cultural practices were applied as recommended.

\subsection{Statistical analysis}

Analysis of variance for a randomized complete block design was done according to (Gomez and Gomez, 1984) and (Draper and Smith, 1981) to the data of grain yield. Three response models were fitted to the grain yield data for the tested cultivar during the first, the second and the third seasons according to Neter et al. (1990) and Steel and Torrie (1980).

\subsection{Nitrogen response curve Models}

To describe maize grain yield response to $\mathrm{N}$ fertilizer, four statistical models (linear, quadratic, exponential, and square root) were fitted to the data using the regression curve procedure of the SPSS software. Economically optimum $\mathrm{N}$ rates (EONR) for the four models were computed for grain yields. The EONR ( $\mathrm{kg} \mathrm{N}$ fed) is defined as the rate of $\mathrm{N}$ application where $£$. E. 1 of additional $\mathrm{N}$ fertilizer returned $£$. E. 1 of maize, and it describes the minimum rate of $\mathrm{N}$ application required to maximize economic return. This analysis assumes that $\mathrm{N}$ fertilizer costs are the only variable costs and that all other costs are fixed. The EONR was calculated by setting the first derivative of the $\mathrm{N}$ response curve equal to the ratio between the cost of fertilizer and the price of maize for the four tested models (Dustin et al., 2004).

For the four statistical models, $\mathrm{Y}$ is the grain yield in $\operatorname{ard} / \mathrm{fed}, \mathrm{N}$ is the $\mathrm{N}$ fertilization rate in $\mathrm{kg}$ $\mathrm{N}$ fed, and $\mathrm{a}, \mathrm{b}$, and $\mathrm{c}$ are parameter estimates using the regression curve procedure (Gilles Bélanger et al., 2000).

The linear model is

$Y=a+b N$

The quadratic model is

$Y=a+b N+c N 2$

The square root model is $\quad \mathrm{Y}=\mathrm{a}+\mathrm{bN} 1 / 2$

The exponential model is $\quad \mathrm{Y}=\mathrm{e}(\mathrm{a}+\mathrm{bN})$

The coefficients of determination $\left(\mathrm{R}^{2}\right)$, standard error of estimate (SE) and significance of the model were the bases considered comparing among the above mentioned response models. The significant model that had the highest $\left(\mathrm{R}^{2}\right)$ and the lowest SE was the best model for describing the relationship between grain yield and $\mathrm{N}$ fertilization.

Economically Optimum Nitrogen Rate and Yield at Economically Optimum Nitrogen Rate (EONR) were calculated for $\mathrm{N}$ rate and the yield response to $\mathrm{N}$ was calculated for all treatments. If the yield did not significantly increase with $\mathrm{N}$ application, the EONR was set at zero. If the yield curve function fitted a simple linear model, the EONR was the maximum $\mathrm{N}$ rate used (in this case

Table (1): Mechanical and chemical analysis of the soil at the experimental sites during the three seasons.

\begin{tabular}{|l|c|c|c|}
\hline Properties & $\mathbf{2 0 1 0}$ & $\mathbf{2 0 1 1}$ & $\mathbf{2 0 1 2}$ \\
\hline Sand \% & 22.19 & 14.42 & 19.68 \\
\hline Silt \% & 32.60 & 28.58 & 34.6 \\
\hline Clay \% & 49.25 & 57.00 & 43.78 \\
\hline Texture & Clay & Clay & Clay \\
\hline pH1:2.5 & 8.15 & 8.10 & 8.20 \\
\hline O.M \% & 2.04 & 2.02 & 2.04 \\
\hline CEC m.e./100 g soil & 36.0 & 36.20 & 36.0 \\
\hline Total N \% & 0.180 & 0.156 & 0.157 \\
\hline NH4 ppm & 5.70 & 5.90 & 15.20 \\
\hline NO2 ppm & 0.11 & 0.32 & 0.23 \\
\hline NO3 ppm & 20.20 & 15.13 & 19.30 \\
\hline Available $(\mathrm{p})$ ppm & 15.20 & 12.30 & 9.25 \\
\hline Available $(\mathrm{k}) \mathrm{m} . \mathrm{e} . / 100 \mathrm{~g}$ soil & 0.91 & 0.91 & 0.90 \\
\hline
\end{tabular}


Table (2): Costs and returns of maize production under $\mathrm{N}$ nitrogen treatments ( $£$ E./fed).

\begin{tabular}{|l|c|c|c|}
\hline Production Activity & $\mathbf{2 0 1 0}$ & $\mathbf{2 0 1 1}$ & $\mathbf{2 0 1 2}$ \\
\hline Land preparation & 90 & 110 & 120 \\
\hline Seeding\& planting & 93 & 115 & 200 \\
\hline Irrigation & 120 & 240 & 240 \\
\hline Fertilization & 480 & 640 & 640 \\
\hline Weeding & 280 & 350 & 350 \\
\hline Pest Control & 20 & 30 & 30 \\
\hline Harvesting & 225 & 350 & 350 \\
\hline Transportation & 60 & 80 & 80 \\
\hline Other Expenses & 60 & 80 & 80 \\
\hline Total without Rent & 1428 & 1995 & 2090 \\
\hline Rent & 1000 & 1666.67 & 1333.33 \\
\hline Total Cost & 2428 & 3661.67 & 3423.33 \\
\hline Yield (ard/fed.) & 24.2 & 21.8 & 26.0 \\
\hline The price of maize & $£$ E $193 /$ ard & $£$ E 262/ard & $£$ E 270/ard \\
\hline Main crop value & 4670.6 & 5711.6 & 7020 \\
\hline Secondary crop value & 190 & 200 & 200 \\
\hline Total Revenue & 4860.6 & 5911.6 & 7220 \\
\hline Net Return & 2397.86 & 2049.93 & 3596.67 \\
\hline
\end{tabular}

$120 \mathrm{~kg} \mathrm{~N}$ fed). If the yield curve function fitted a quadratic model, the EONR was calculated by setting the derivative of the gross return function in the following equation:

Net return $=\left(a+b \times N\right.$ rate $+c \times N$ rate $\left.^{2}\right) \times\left(P_{c}-\right.$ $\left.P_{n}\right) \times N$ rate

Equal to zero. The gross return was calculated using this equation, where b0, b1, and b2 are intercept, linear, and quadratic parameters, respectively; $\mathrm{pc}$ is the price of maize; and $\mathrm{pn}$ is the cost of N. The prices of maize were ( $£$ E 240/ard, 160/ard and 140/ard) in the three seasons, respectively. The prices of $\mathrm{N}$ fertilizer per kilogram were ( $£ \mathrm{E} 4 / \mathrm{kg}$ and $5.3 / \mathrm{kg}$ ) at the time of the experiment. The detailed costs of the inputs and other farm operations are presented in Table (2). Gross return comparison was made between EONR and a uniform $\mathrm{N}$ rate recommendation made by the University of Minnesota (Mamo et al., 2003).

\section{RESULTS AND DISCUSSION}

\subsection{Effects of nitrogen fertilizer on grain yield}

The results of nitrogen fertilizer rates on grain yield ard/fed in maize single cross hybrid (S.C.10) are presented in Table (3). Grain yield (ard/fed) was significantly affected by $\mathrm{N}$ rates in the three seasons of the study.

These results indicated clearly that nitrogen levels had a significant effect on grain yield (ard (fed) in all the studied seasons. Application of $30,60,90,120$ and $150 \mathrm{~kg} \mathrm{~N} / \mathrm{fed}$ increased grain yield /fed by $28.57 \%, 50.99 \%, 60.32,70.79$ and $88.26 \%$ in the first season, 59.24\%, 104.18\%, $140.46,164.29$ and $206.42 \%$ in the second season and $28.96 \%, 67.19 \%, 78.23,102.12$ and 125.74 in the third season compared to the check treatment, respectively. The highest grain yield $(30.39,31.50$ and $35.18 \mathrm{ard} / \mathrm{fed}$ ) was obtained by using $150 \mathrm{~kg}$ $\mathrm{N} / \mathrm{fed}$, while the lowest grain yield of (16.14, 10.28 and $15.58 \mathrm{ard} / \mathrm{fed}$ was produced at the check treatment (zero nitrogen fertilizer) in all seasons, respectively. Also, the result of gross income was the same results of nitrogen fertilizer rates on grain yield ard/fed.

\subsection{Benefit cost ratio analysis}

Using the benefit cost ratio allows researchers to make decisions on the negatives and positives of investing in different nitrogen fertilizer rates. In other words, using benefit cost ratio analysis allows an entity to decide whether or not the benefits of a given nitrogen fertilizer rate outweigh the actual costs compared with the zero nitrogen fertilizer rate.

The results clearly indicated that the application of $30,60,90,120$ and $150 \mathrm{~kg} \mathrm{~N} / \mathrm{fed}$ realized $(1.409,1.674,1.691,1.726,1.863$ and $1.582)$ in the first season 2010, $(-0.177,0.005$, $0.130,0.187,0.319$ and 0.021$)$ in the second season 2011, in $2012(-0.044,0.175,0.192,0.288$, 


\subsection{5 and 0.145 )}

\subsection{Analysis of $\mathrm{N}$ response curve}

Linear, quadratic, exponential and square root models were fitted to the grain yield data for the tested maize cultivar in the three seasons, respectively. Three bases were considered to compare among the four models $i$. $e$ coefficient of determination $\left(\mathrm{R}^{2}\right)$, estimate standard error (SE) and the significance of the model. The significant model which had highest $\mathrm{R}^{2}$ and lowest SE was the best model fitted to the yield data.

Table (4) shows the coefficient of determination $\left(\mathrm{R}^{2}\right)$, the standard error of estimate (SE) and the calculated $\mathrm{F}$ value of the four models to study the response of maize grain yield to $\mathrm{N}$ fertilizer during 2010, 2011 and 2012 seasons. Results clearly indicate that the best value of coefficient of determination, $\mathrm{R}^{2}$, was in favor of quadratic model for the tested cultivar in the three seasons of the study. The values of $\mathrm{R}^{2}$ of quadratic model were $93.4 \%, 91.8 \%$ and $84.3 \%$ in the three seasons, respectively. The second degree model had a standard error of estimate less than those of linear, exponential and square root models. Moreover, quadratic model had a significant calculated $\mathrm{F}$ value for the tested cultivar in the three seasons.

Therefore, the quadratic model was the best of the response models tested for describing the response of grain yield of maize cultivar S. C. 10 nitrogen fertilizer, (Table 4 and Figs 1 and 2 ). These results are similar to those obtained by Schlegel et al. (1996) and El-Douby et al. (2001) who reported that the relation between grain yield of maize and $\mathrm{N}$ fertilizer followed the quadratic model.

Maximum nitrogen rates estimated by the quadratic equation were $121.053,120.645$ and

Table (3): Effect of nitrogen fertilizer rates on grain yield (ard/fed) of maize cultivar(S.C.10) in 2010, 2011 and 2012 seasons.

\begin{tabular}{|c|c|c|c|c|c|c|c|c|}
\hline Year & Characters & $\mathbf{0}$ & 30 & 60 & 90 & 120 & 150 & Mean \\
\hline \multirow{7}{*}{ 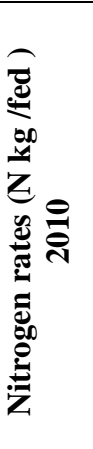 } & Yield (ard/fed) & $\begin{array}{c}16.144 \\
\text { A }\end{array}$ & $\begin{array}{c}20.756 \\
\mathrm{~B}\end{array}$ & $\begin{array}{c}24.377 \\
\Gamma\end{array}$ & $\begin{array}{c}25.882 \\
\text { CD }\end{array}$ & $\begin{array}{c}27.573 \\
D\end{array}$ & $\begin{array}{c}30.392 \\
\mathrm{~F}\end{array}$ & 24.187 \\
\hline & $\%$ & & 28.57 & 50.99 & 60.32 & 70.79 & 88.26 & 49.83 \\
\hline & Gross income & $\begin{array}{c}3115.7 \\
\text { A }\end{array}$ & $\begin{array}{c}4005.9 \\
\text { B }\end{array}$ & $\begin{array}{c}4704.8 \\
C\end{array}$ & $\begin{array}{c}4995.2 \\
\text { CD }\end{array}$ & $\begin{array}{c}5321.7 \\
\text { D }\end{array}$ & $\begin{array}{c}5865.6 \\
\mathrm{E}\end{array}$ & 4668.2 \\
\hline & $\%$ & & 28.57 & 51.00 & 60.32 & 70.81 & 88.25 & 49.83 \\
\hline & Profit & 1167.7 & 1937.9 & 2516.8 & 2687.2 & 2893.7 & 3317.6 & 2420.2 \\
\hline & Total cost & 1948.0 & 2068.0 & 2188.0 & 2308.0 & 2428.0 & 2548.0 & 2248.0 \\
\hline & Benefit cost ratio & 0.599 & 0.937 & 1.150 & 1.164 & 1.192 & 1.302 & 1.057 \\
\hline \multirow{7}{*}{ 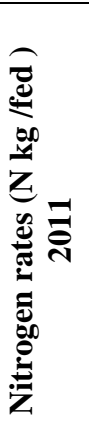 } & Yield (ard/fed) & $\begin{array}{c}10.280 \\
\mathrm{~A}\end{array}$ & $\begin{array}{c}16.37 \\
\mathrm{~B}\end{array}$ & $\begin{array}{c}20.99 \\
\mathrm{C}\end{array}$ & $\begin{array}{c}24.72 \\
\text { D }\end{array}$ & $\begin{array}{c}27.17 \\
\mathrm{D}\end{array}$ & $\begin{array}{c}31.500 \\
E\end{array}$ & 21.84 \\
\hline & $\%$ & & 59.24 & 104.18 & 140.46 & 164.29 & 206.42 & 112.45 \\
\hline & Gross income & $\begin{array}{c}2693.3 \\
\text { A }\end{array}$ & $\begin{array}{c}4288.4 \\
\text { B }\end{array}$ & $\begin{array}{c}5501.6 \\
\mathrm{C}\end{array}$ & $\begin{array}{c}6476.6 \\
\text { D }\end{array}$ & $\begin{array}{c}7118.5 \\
\text { D }\end{array}$ & $\begin{array}{c}8254.2 \\
\text { E }\end{array}$ & 5722.1 \\
\hline & $\%$ & & 59.23 & 104.27 & 140.48 & 164.32 & 206.48 & 112.46 \\
\hline & Profit & -328.4 & 1106.8 & 2159.9 & 2974.9 & 3456.8 & 4432.5 & 2300.4 \\
\hline & Total cost & 3021.7 & 3181.6 & 3341.7 & 3501.7 & 3661.7 & 3821.7 & 3421.7 \\
\hline & Benefit cost ratio & -0.109 & 0.348 & 0.646 & 0.849 & 0.944 & 1.160 & 0.639 \\
\hline \multirow{7}{*}{ 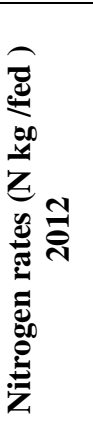 } & Yield (ard/fed) & $\begin{array}{c}15.587 \\
\mathrm{~A}\end{array}$ & $\begin{array}{c}20.10 \\
A\end{array}$ & $\begin{array}{c}26.06 \\
B\end{array}$ & $\begin{array}{c}27.78 \\
\mathrm{~B} C\end{array}$ & $\begin{array}{c}31.503 \\
\text { CD }\end{array}$ & $\begin{array}{c}35.186 \\
D\end{array}$ & 26.04 \\
\hline & $\%$ & & 28.96 & 67.19 & 78.23 & 102.12 & 125.74 & 67.06 \\
\hline & Gross income & $\begin{array}{c}4208.5 \\
\text { A }\end{array}$ & $\begin{array}{c}5428.1 \\
\text { A }\end{array}$ & $\begin{array}{c}7034.9 \\
\text { B }\end{array}$ & $\begin{array}{c}7499.9 \\
\text { B }\end{array}$ & $\begin{array}{c}8505.9 \\
\text { BC }\end{array}$ & $\begin{array}{c}9500.3 \\
\text { D }\end{array}$ & 7029.6 \\
\hline & $\%$ & & 28.98 & 67.16 & 78.21 & 102.11 & 125.74 & 67.03 \\
\hline & Profit & 1425.2 & 2484.8 & 3931.6 & 4236.6 & 5082.6 & 5917 & 3846.3 \\
\hline & Total cost & 2783.3 & 2943.3 & 3103.3 & 3263.3 & 3423.3 & 3583.3 & 3183.3 \\
\hline & Benefit cost ratio & 0.512 & 0.844 & 1.267 & 1.298 & 1.485 & 1.651 & 1.176 \\
\hline
\end{tabular}

*LSD value at $1 \%$ 


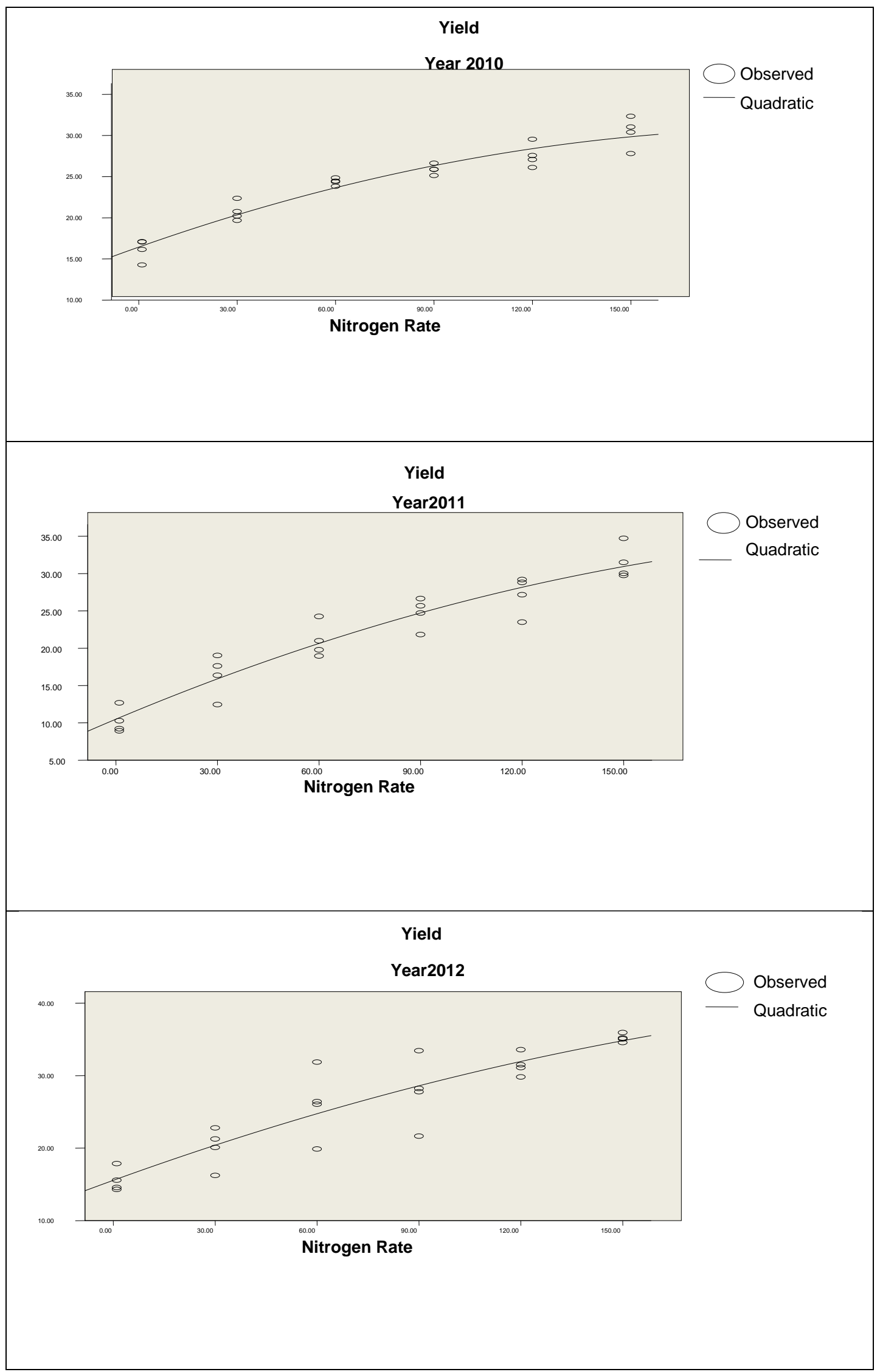

Fig. (1): Nitrogen response curves 
Table (4): Coefficient values of determination $\left(\mathbf{R}^{2}\right)$, standard error of estimate (SE) and calculated $F$ value for models describing the relationship between $N$ rate and grain yield of maize cultivars in 2010, 2011 and 2012 seasons.

\begin{tabular}{|c|c|c|c|c|c|c|}
\hline Year & $\begin{array}{l}\text { Cultivars } \\
\text { Models }\end{array}$ & Regression equations & $\mathbf{R}^{2} \%$ & S.E. & F (cal) & $\mathbf{P}$ \\
\hline \multirow{4}{*}{ 록 } & Linear & $\mathrm{Y}=17.53+0.0887 \mathrm{~N}$ & 91.0 & 1.495 & 221.9 & $\overline{0.00}$ \\
\hline & Quadratic & $\begin{array}{c}\mathrm{Y}=16.537+0.138 \mathrm{~N}- \\
0.00057 \mathrm{~N} * * 2\end{array}$ & 93.4 & 1.308 & 148.9 & $\mathbf{0 . 0 0}$ \\
\hline & Square root & $\mathrm{Y}=14.55+1.23 \mathrm{~N}^{\wedge 0.5}$ & 93.8 & 1.537 & 332.8 & 0.00 \\
\hline & Exponential & $Y=17.687+0.004 \exp (N)$ & 87.2 & 0.080 & 149.5 & $\overline{0.00}$ \\
\hline \multirow{4}{*}{$\overline{\text { సె }}$} & Linear & $\mathrm{Y}=11.679+0.135 \mathrm{~N}$ & 90.7 & 2.327 & 213.6 & 0.00 \\
\hline & Quadratic & $\begin{aligned} Y= & 10.638+0.187 \mathrm{~N}- \\
& 0.000775 \mathrm{~N} * * 2\end{aligned}$ & 91.8 & 2.231 & 117.6 & 0.00 \\
\hline & Square root & $\mathrm{Y}==7.35+1.85 \mathrm{~N}^{\wedge 0.5}$ & 90.6 & 5.417 & 213.4 & 0.00 \\
\hline & Exponential & $Y=12.072+0.007 \exp (N)$ & 84.7 & 0.159 & 122.1 & 0.00 \\
\hline \multirow{4}{*}{ בั้ } & Linear & $Y=16.470+0.12754 \mathrm{~N}$ & 83.6 & 3.019 & 112.4 & 0.00 \\
\hline & Quadratic & $\begin{array}{c}Y=15.692+0.1665 \mathrm{~N}- \\
0.0006937 \mathrm{~N} * * 2\end{array}$ & 84.3 & 3.027 & 56.35 & 0.00 \\
\hline & Square root & $\mathrm{Y}==12.51+1.73 \mathrm{~N}^{\wedge 0.5}$ & 82.3 & 9.863 & 102.3 & $\mathbf{0 . 0 0}$ \\
\hline & Exponential & $Y=16.824+0.005 \exp (N)$ & 81.5 & 0.134 & 96.81 & 0.00 \\
\hline
\end{tabular}

$120.129 \mathrm{~kg} \mathrm{~N} / \mathrm{fed}$ in the three seasons, respectively. (Table 5). The results showed that cultivar S.C.10 out yielded in the three seasons at the maximum level of fertilizer nitrogen recording $24.89,21.92$ and $25.69 \mathrm{ard} / \mathrm{fed}$ in the three seasons, respectively.

\subsection{Economic analysis}

The results in Table (6) show the economic analysis of nitrogen fertilizer. In the first season, the optimum nitrogen rate was $106.433 \mathrm{~kg} \mathrm{~N} / \mathrm{fed}$. Grain yield produced by supplying the optimum N dose was $24.77 \mathrm{ard} /$ fed giving return equals to $£$ E $4780.61 /$ fed. In the second season, adding the optimum $\mathrm{N}$ rate $101.53 \mathrm{~kg} \mathrm{~N} / \mathrm{fed}$ gave grain yield of $21.69 \mathrm{ard} / \mathrm{fed}$ and return equal to $£ \mathrm{E}$ $5682.78 /$ fed. In the third season optimum $\mathrm{N}$ dose was $92.84 \mathrm{~kg} / \mathrm{fed}$ gave grain yield $25.17 \mathrm{ard} / \mathrm{fed}$ giving return equals to $£$ E 6795.9/fed. Similar results were obtained by Cerrato and Blackmar (1990), Oberle and Keeney (1990), Vanotti and Bundy (1994), Schlegel et al. (1996) and William et al. (2004).

Price of nitrogen $=£$ E 4/kg-2010 and $£$ E 5.3/kg for 2011 and 2012.

Price of maize grain $=£$ E 193/ard -2010, 262/ard2011 and 270/ard-2012.

Table (5): Quadratic regression equations, maximum nitrogen rate and grain yield at the maximum nitrogen rate for maize cultivars in the 2010, 2011 and 2012 seasons.

\begin{tabular}{|c|c|c|c|}
\hline Seasons & Regression equations & $\begin{array}{c}\text { Maximum } \\
\text { N rate }(\mathrm{kg} / \text { fed })\end{array}$ & $\begin{array}{c}\text { Yield at the maximum } \\
\text { N rate }(\mathrm{kg} / \text { fed })\end{array}$ \\
\hline 2010 & Y=16.537+0.138N-0.00057N $* * 2$ & 121.053 & 24.89 \\
\hline 2011 & Y=10.638+0.187N-0.000775N $* * 2$ & 120.645 & 21.92 \\
\hline 2012 & Y=15.692+0.1665N-.0006937N $* * 2$ & 120.129 & 25.69 \\
\hline
\end{tabular}

Table ( 6): Economic analysis of nitrogen fertilization for maize cultivars in 2010, 2011 and 2012 seasons.

\begin{tabular}{|c|c|c|c|}
\hline Seasons & Optimum N rate $(\mathbf{k g} / \mathbf{f e d})$ & Yield at the optimum N rate $(\mathbf{a r d} / \mathbf{f e d})$ & Net return $(£ \mathbf{E} / \mathbf{f e d})$ \\
\hline 2010 & 106.433 & 24.77 & 4780.61 \\
\hline 2011 & 101.530 & 21.69 & 5682.78 \\
\hline 2012 & 92.840 & 25.17 & 6795.9 \\
\hline
\end{tabular}




\section{REFERENCES}

Cerrato M. E. and Blackmer A. M. (1990). Comparison of Models for describing corn yield response to nitrogen fertilizer. Agron. J., 82:138-143.

Draper N. R. and Smith H. (1981): Applied regression analysis. John Wiley and Sons Inc., New York, PP:397- 402.

Dustin A. B., Young D. L. , Huggins D. R. and Pan W.L. (2004). Economically optimal nitrogen fertilization for yield and protein in hard red spring wheat. Agronomy J., 96:116-123.

El-Douby K. A., Ali E. A., Toaima S. E. A. and Abdel Aziz A. M. (2001). Effect of nitrogen fertilizer, defoliation and plant density on maize grain yield. Egypt. J. Agric. Res., 79(3): 965-982.

Gilles Bélanger J. R. Walsh, Richards J. E., Milburn P. H. and Ziadi N. (2000). Comparison of three statistical models describing potato yield response to nitrogen fertilizer. Agronomy Journal, 92:902-908.

Gomez K. A. and Gomez A. A. (1984): Statistical procedures for agricultural research. John Wiley \& Sons, Inc. New York, USA.

Jackosn M.L., (1973). "Soil Chemical Analysis" [renice Hall of India private limited. New Delhi, Indian.

Mamo M., Malzer G. L., Mulla D. J., Huggins D.
R. and Strock J. (2003). Spatial and temporal variation in economically optimum nitrogen rate for corn. Agronomy Journal, 95:958-964.

Neter J., Wasserman W. and Kunter M. H. (1990). Applied Linear Statistical Models. 3rd ed., IRWIN, Homewood, Boston, U.S.A.

Oberle S. L. and Keeney D. R. (1990): Soil type, precipitation, and fertilizer $\mathrm{N}$ effects on corn yields. J. Prod. Agric, . 3:522-527.

Schlegel A.J., Dhuyvetter K.C. and Havlin J.L. ( 1996). Economic and environmental impacts of long-term nitrogen and phosphorus fertilization. J. Prod. Agric., 9: 114-118.

Steel R. G. D. and Torrie J. H. (1980): Principles and Procedures of Statistics, a Biometerical Approach. Mc-Graw-Hill Book Co., 2nd ed, New York, U.A.S.

Vanotti M. B. and Bundy L. G. (1994). An alternative rationale for corn nitrogen fertilizer recommendations. J. Prod. Agric.,243-249.

William J. C., Knoblauch W. A., van Es H. M., Katsvairo T. W. and Glos M. A. (2004). Economics of purchasing a yield monitor for split- planter corn hybrid testing. Agron. J., 96:1469-1474.

$$
\begin{aligned}
& \text { تقييم اقتصادي لمنحنيات استجابة الذرة الثامية للتسميد الآزوتي } \\
& \text { شابون عبدالعزيز منصور - سمير كامل علي اسماعيل* ـ ايمان خليل عباس*** سعيد محمد حسين عيسي ** } \\
& \text { قسم بحوث الذرة الثامية ــ معهد الدحاصيل الحقلية ــ مركز البحوث الزر اعيةـ الجيزة. }
\end{aligned}
$$

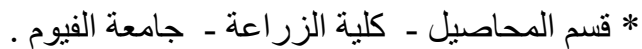

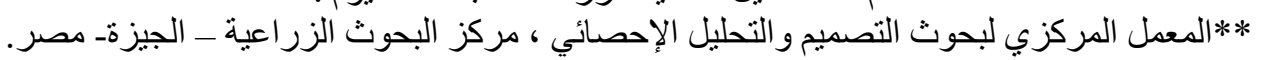

$$
\begin{aligned}
& \text { أقيمت ثلاث تجارب حقلية في محطة البحوث الزر اعية بسدس - مركز البحوث الزر اعية خلال المو اسم ( 2010و } 2011 \text { و }
\end{aligned}
$$

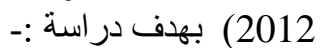

$$
\begin{aligned}
& \text { 1- تقييم تأثير معدلات السماد الآزوتي ( صفر - - 20-60-90- 120- } 150 \text { كم أزوت/فدان) على محصول حبوب الذرة الثامية }
\end{aligned}
$$

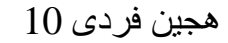

$$
\begin{aligned}
& \text { 2- تحديد انسب درجة لهذة العلاقة بين محصول الحبوب و السماد الآزوتي. }
\end{aligned}
$$

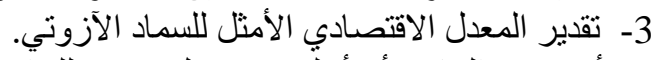

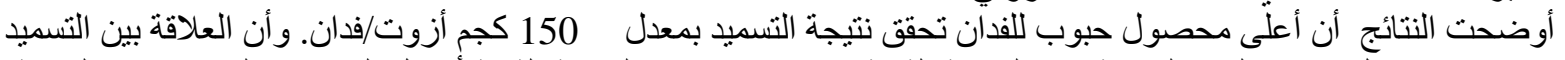

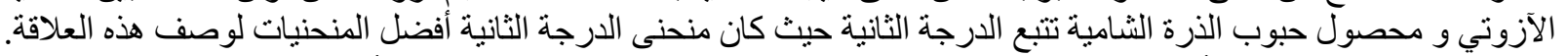

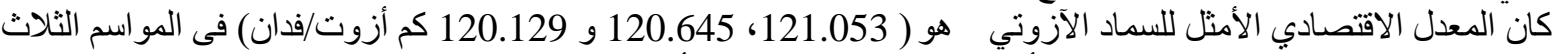

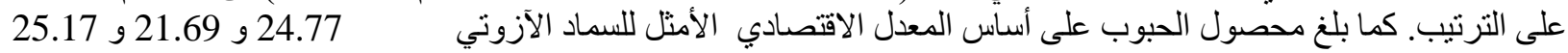

$$
\begin{aligned}
& \text { إردب/فدان فى المو اسم الثلاث على الترتيب ـ وصل الدخل } 4780.61 \text { و } 5682.78 \text { و الأل } 6795.90 \text { جنيها/فدان في المو اسم الثلاث } \\
& \text { على الترتيب. }
\end{aligned}
$$




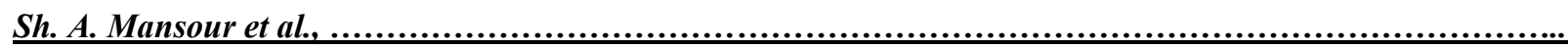

